Tersedia Online di http://journal2.um.ac.id/index.php/jmsp/

ISSN Online : 2541-4429

\title{
MANAJEMEN LAYANAN KHUSUS PONDOK PESANTREN
}

\author{
Arini Amalia \\ MTs SA Hidayatul Mubtadiin Kanigoro Blitar \\ Tlogo, Kanigoro, Blitar \\ E-mail: ariniamaliaap@gmail.com
}

\begin{abstract}
The purpose of this research is to describe (1) planning of special service boarding school at Madrasah Aliyah Ma'arif NU Blitar City; (2) organizing special service boarding school at Madrasah Aliyah Ma'arif NU Blitar City; (3) implementation of special service boarding school at Madrasah Aliyah Ma' arif NU Blitar City; (4) supervision of special service boarding school at Madrasah Aliyah Ma'arif NU Blitar City. This research uses qualitative approach with case study research type. Data were collected through interviews, observation, and documentation. The results of the research include planning, organizing, implementing and supervising special services of boarding school in Madrasah Aliyah Ma'arif NU City of Blitar.
\end{abstract}

Keywords: management, special service, boarding school

\begin{abstract}
Abstrak: Penelitian ini dilaksanakan dengan tujuan untuk mendeskripsikan (1) Perencanaan Layanan Khusus Pondok Pesantren di Madrasah Aliyah Ma'arif NU Kota Blitar; (2) Pengorganisasian Layanan Khusus Pondok Pesantren di Madrasah Aliyah Ma'arif NU Kota Blitar; (3)Pelaksanaan Layanan Khusus Pondok Pesantren di Madrasah Aliyah Ma'arif NU Kota Blitar; (4) Pengawasan Layanan Khusus Pondok Pesantren di Madrasah Aliyah Ma'arif NU Kota Blitar. Penelitian ini menggunakan pendekatan kualitatif dengan jenis penelitian studi kasus. Data dikumpulkan melalui wawancara, observasi, dan dokumentasi. Hasil penelitian mencakup perencanaan, pengorganisasian, pelaksanaan, dan pengawasan layanan khusus pondok ppesantren di Madrasah Aliyah Ma'arif NU Kota Blitar.
\end{abstract}

Kata Kunci: manajemen, layanan khusus, pondok pesantren

Manajemen layanan khusus pondok pesantren merupakan salah satu layanan yang diberikan oleh madrasah untuk para peserta didik. Asrama merupakan bentuk pengoptimalan untuk kegiatan pembelajaran di lembaga pendidikan. Keberadaannya sebagai penunjang kegiatan belajar agar terlaksana dengan baik, efektif dan efisisen. Selain itu, dengan adanya asrama para ustadz/ustadzah dapat memantau kegiatan santri baik saat di madrasah maupun di asrama. Sehingga memudahkan untuk melakukan pengawasan terhadap santrinya.

Madrasah Aliyah Ma'arif Nahdlotul Ulama' (MAM NU) merupakan salah satu madrasah di Kota Blitar yang berada di bawah naungan NU. Pada awalnya MAM NU Blitar ini bernama MAK (Madrasah Aliyah Keagamaan) yang kemudian berganti nama. Meskipun demikian madrasah ini tetap berada dibawah naungan NU. Asrama yang dimiliki madrasah ini merupakan hasil musyawarah pengurus NU, sesepuh madrasah, dan Komite. Karena asrama ini berada di bawah naungan NU, maka diresmikan menjadi pondok pesantren dengan nama Nurul Ulum.

Seluruh siswa-siswi yang belajar di madrasah ini wajib tinggal di pondok pesantren. Fasilitas dan kebutuhannya untuk sehari-hari pun sudah disediakan. Seperti, koperasi, air minum bersih, kamar beserta lemari, Poskestren (Pos Kesehatan Pesantren, kantin dan lain sebagainya. Adanya fasilitas yang sudah disediakan, diharapkan para snatri tidak perlu keluar area pondok pesantren untuk berbelanja agar tidak mengganggu kegiatan belajar baik di madrasah formal maupun kegiatan 
di pondok pesantren.

Kegiatan belajar dimadrasah ini tidak hanya di bidang akademik saja tetapi juga terdapat pembelajaran agama yang diberikan untuk seluruh santri yaitu mengaji atau diniyah. Pembelajaran akademik dilaksankan pada pagi hari yait mulai pukul 07.00 sampai pukul 12.00. Setelah selesai seluruh santri dipersilakan istirahat untuk sholat dan makan, kemudian belajar diniyah yang dilaksanakan pada sore hari yaitu pukul 13.20 sampai pukul 16.00. kegiatan tersebut rutin dilaksanakan setiap hari oleh seluruh santri. Sedangkan untuk pembelajaran di pesantren dilaksanakan pada malam hari yaitu ba'da maghrib sampai pukul 20.00. Pembelajaran di pesantren ada 2, yaitu mengaji kitab kuning dan mengaji Al-Qur'an dengan metode Utsmani. Setiap kegiatan memiliki penanggungjawab masing-masing sehingga memudahkan pengasuh dalam melakukan pengawasan.

Pengawasan dilakukan oleh pimpinan madrasah, di dalam oganisasi sekolah bisa dilakukan kepala madrasah dan yayasan. Triwiyanto (2015:67) mengatakan bahwa organisasi sekolah perlu dijalankan dengan baik karena tugas guru dan kepala sekolah tidak hanya mengajar dan mendidik saja, semua harus bertanggung jawab dan diikutsertakan dalam menjalankan roda kehidupan sekolah secara keseluruhan. Dengan demikian, agar tidak bertabrakan dalam memegang dan menjalankan tugasnya masing-masing, diperlukan organisasi sekolah yang baik dan teratur.

\section{METODE}

Penelitian ini menggunakan pendekatan kualitatif, peneliti ingin mengungkap tentang manajemen layanan khusus pondok pesantren di Madarasah Aliyah Ma'arif Nahdlotul Ulama' Kota Blitar secara mendalam. Pendekatan kualitatif merupakan suatu proses penelitian yang dilakukan secara sistematis dan intensif untuk memperoleh pengetahuan tentang fenomena sosial dengan menggunakan fenomena sosial itu sendiri (Wiyono, 2007:72). Penelitian ini menggunakan jenis studi kasus, karena peneliti terfokus pada satu latar yaitu MAM NU Kota Blitar. Menurut Ulfatin (2013:48) studi kasus adalah "suatu metode penyelidikan secara langsung dengan latar yang alamiah dan memusatkan perhatian pada suatu peristiwa secara intensif dan rinci". Penelitian ini menggunakan jenis penelitian studi kasus, karena peneliti ingin menemukan dan menganalisis masalah yang ada lebih mendalam, menyeluruh, dan utuh. Studi kasus lebih menekankan pengungkapan fakta yang terdapat di lapangan secara rinci dan mendalam pada suatu objek atau peristiwa dari lapangan.

Kehadiran peneliti mutlak diperlukan karena peneliti bertindak sebagai instrumen kunci untuk mendapatkan informasi secara mendalam terkait fenomena yang ingin diteliti di lokasi penelitian. Sesuai dengan pendapat Ulfatin (2013:182) "peneliti sebagai instrumen kunci sekaligus pengumpul data penelitian. pada penelitian kualitatif, kehadiran peneliti dilapangan mutlak diperlukan". Pihak yang menjadi sumber data dalam penelitian ini yaitu kepala madrasah, pengasuh pondok pesantren, pendamping pondok pesantren, dan ketua pondok pesantren. Teknik pengumpulan data melalui observasi, wawancara, dan studi dokumentasi.

Analisis data dilakukan selama proses penelitian berlangsung dan setelah semua data terkumpul. Menurut Ulfatin (2013:234) "analisis data dalam penelitian kualitatif adalah proses sistematis untuk mencari dan mengatur transkrip wawancara, catatan lapangan, dan materi-materi lain untuk menemukan apa yang penting dilaporkan kepada orang lain sebagai temuan penelitian". Pertama, melakukan reduksi data yaitu memilah-milah data yang ditemukan di lapangan, kemudian memilih data yang tepat sesuai fokus penelitian. Kedua, display data yaitu menyajikan data dengan menguraikan hasil penelitian yang ada kemudian meringkasnya dalam bentuk bagan sehingga diperoleh informasi yang memiliki kesimpulan dan makna yang relevan dengan fokus penelitian. Ketiga, melakukan verifikasi data yaitu menarik makna dari data yang ditampilkan sehingga diperoleh kesimpulan yang kredibel.

Pengecekan keabsahan data dilakukan untuk memperoleh kesimpulan yang tepat dan untuk menghindari kesalahan dalam penelitian kualitatif. Pengecekan keabsahan data digunakan untuk menyanggah balik tentang tuduhan penelitian kualitatif yang mengatakan tidak ilmiah (Moleong, 2007:320). Teknik pengecekan keabsahan data dalam penelitian ini dipaparkan dengan trianggulasi, kecukupan referensial, 
pengecekan keanggotaan, dan perpanjangan keikutsertaan. Tahap-tahap yang ditempuh dalam penelitian ini yaitu tahap perencanaan atau tahap sebelum ke lapangan, tahap pekerjaan lapanagan, tahap analisis data, dan terakhir tahap penulisan laporan.

\section{HASIL}

Perencanaan layanan khusus pondok pesantren di MAM NU Kota Blitar dilakukan pada awal tahun pelajaran baru. Perencanaan program kegiatan sudah menyatu dengan program madrasah. Namun dalam menyusun program tidak melibatkan seluruh civitas akademik yang ada di madrasah. Keseluruhan program baik yang ada di madrasah dan di pondok pesantren dapat diketahui pada saat dilakukan sidang pleno atau workshop. Pada kegiatan ini seluruh civitas mendapat masukan dari berbagai pihak kemudian memperbaiki program-program yang sudah disusun. Kegiatan workshop ini akan menghasilkan perencanaan program serta rician berbagai kegiatan yang akan dilakukan 1 semester ke depan dan 1 tahun ke depan. Pembagian tugas dan tanggungjawab di madrasah dan pondok pesantren dilakukan sekalian pada saat kegiatan workshop ini. Pihak yang terlibat dalam kegiatan ini seluruh civitas akademik mulai dari pimpinan yayasan, kepala madrasah, kepala madrasah diniyah, pengasuh pondok pesantren, dan seluruh ustadz/ustadzah yayasan. Selain pembagian tugas, kegiatan ini juga mengatur jadwal santri mulai dari bangun sampai tidur kembali.

Pengorganisasian pondok pesantren dan madrasah menjadi satu kesatuan dengan yayasan lembaga pendidikan ma'arif NU kota Blitar. Pengelolaan pesantren dan madrasah di MAM NU Kota Blitar berupa struktur organisasi dan pembagian tugas masing-masing serta tanggungjawab yang sesuai kedudukn dan wewenang. Sehingga setiap kegiatan dpat dikoordinasikan dengan baik. Tugas dan wewenang ustadz/ustadzah madrasah sudah tertulis dalam tugas pokok dan fungsinyanya. Pengasuh pondok pesantren bertugas mengatur seluruh kegiatan yang terlaksana di pondok pesantren. Selain itu, memimpin kegiatan evaluasi dan mengontrol seluruh kegiatan. Pengasuh dibantu oleh pendamping pondok pesantren guna untuk membangunkan santri pagi hari, mengurusi santri yang sakit, mengontrol kegiatan santri, mengobrak-obrak santri yang malas, dan memberi hukuman bagi santri yang melakukan pelanggaran sebelumnya sudah dikoordinasikan kepada pengasuh. Di dalam pondok pesantren, juga terdapat ketua. Ketua di sini bertugas menghandel semua kegiatan santri yang kemudian dibagi ke masing-masing devisi. Akan tetapi, jika sudah masuk pendidikan formal maka itu tugas dari pihak madrasah. Keberadaan santri merupakan tanggung jawab para pengasuh. Akan tetapi, pada saat pembelajaran di madrasah formal penanggung jawabnya yaitu pihak madrasah. Sebaliknya, pada saat santri sudah berada di lingkungan pondok pesantren merupakan tanggung jawab pengasuh. Meskipun demikian kedua pihak madrasah dan pondok pesantren tetap saling berkoordinasi untuk mengawasi para santri.

Pembelajaran di MAM NU Kota Blitar terbagi menjadi 2 yaitu: pertama, pembelajaran formal dimulai jam 07.00 sampai 12.00 kemudian dilanjutkan pembelajaran sore pada jam 13.20 samapai 16.00. Kedua, pembelajaran diniyah dimulai pukul 18.20 sampai 20.00. Pembelajaran diniyah pada malam hari dibagi menjadi dua yaitu mengaji kitab kuning dan A-Quran dengan metode Utsmani. Pembelajaran ini ada dua tingkatan yaitu ula dan wustho. Kegiatan ini dilaksanakan pada hari Jum'at sampai hari Rabu dengan pembagian 3 hari mengaji kitab dan 3 hari mengaji Al-Qur'an. Sedangkan pada hari Kamis kegiatan bersama membaca do'a tahlil, istighosah, diba', dan lain sebagainya.diselasela kegiatan santri yang padat terdapat jadwal makan yang sudah diatur 3 kali sehari. Jadwal pengambilan makan pagi dimulai jam 06.00 sampai 06.30, makan siang dimulai jam 12.00 sampai jam 13.00, dan makan sore dimulai pukul 16.00 sampai 18.00 . Apabila terdapat santri yang tidak bisa mengambil makan sesuai jadwal maka harus lapor kepada petugas. Sistem distribusi makan dibagi ke tiga titik untuk menghindari antrian panjang. Santri dipersilakan mengambil nasi sesuai keinginan sedangkan lauknya dibagikan oleh petugas untuk menghindari santri yang mengambil jatah lebih. Bagi santri yang melakukan pelanggaran akan mendapat sanksi dari pengurus. Sanksi tersebut dapat berupa teguran, membersihkan area pondok pesantren, membersihkan kamar mandi, dan mencuci 
pakaian.

Kegiatan evaluasi atau pengawasan di MAM NU Kota Blitar ditujukan agar pengelolaan organisasi sesuai dengan tujuan perencanaan yang telah ditetapkan sebelumnya. Evaluasi di MAM NU Kota Blitar dibagi ke masing-masing penanggungjawab, namun ada satu kegiatan evaluasi yang dilaksanakan dalam satu yayasan. Pertama, evaluasi pondok pesantren dilaksanakan oleh pengasuh beserta pendamping dan ketua seminggu sekali. Kegiatan ini, evaluasi kegiatan yang sudah terlaksana dan yang dilaksanakan. Kedua, evaluasi pengurus madin, dilaksanakan seminggu sekali setiap hari Rabu, pembahasan mengenai keterlaksanaan kegiatan madin dan kendala yang ditemui. Ketiga, evaluasi para civitas akademik madrasah setiap sebulan sekali. Komponen yang dievaluasi di madrasah bersifat totalitas yaitu pertama kegiatan santri mulai dari bangu sampai tidur lagi, sholat tahajud, sholat subuh, sholat dhuha, keteraturan makannya, ketertiban masuk kelas, KBM, dan tadarus. Ketiga, realisasi program madrasah dan evaluasi KBM dalam satu ulan yang sudah terlaksana atau kegiatan lainnya.

\section{PEMBAHASAN}

Perencanaan layanan khusus pondok pesantren dilakukan setiap awal tahun pelajaran baru. Pada kesempatan ini membahas kegiatan apa yang akan dilaksanakan dan bagaimana cara mencapainya. Penentuan kegiatan di MAM NU Kota Blitar ini dibentuk dalam kegiatan workshop yang melibatkan seluruh pihak Yayasan Ma'arif yang bekerja didalamnya. Kegiatan ini dipimpin lagsung oleh direktur perguruan ma' arif. Menurut Aryawiga (2012) yang dimaksud perencanaan di sini menitikberatkan pada usaha untuk menyeleksi dan menghubungkan sesuatu dengan kepentingan masa yang akan datang serta usaha untuk mencapainya. Semua program kegiatan dari masing-masing satuan tidak serta merta diterima begitu saja. Akan tetapi dibicarakan pada saat workshop dan akan direvisi bersama pimpinan serta mendapatkan masukan/saran dari berbagai pihak yang mengikuti kegiatan workshop tersebut. Kemudian, jadwal untuk para santri disesuaikan dengan jadwal tahun sebelumnya namun juga ada beberapa yang perlu direvisi. Mulai jadwal tidur santri, makan, ibadah, belajar dan kegiatan lainnya baik saat dimadrasah maupun saat berada dipondok pesantren. Selain itu, hubungan personal pondok pesantren, madrasah dengan masyarakat juga dibutuhkan untuk memupuk rasa persaudaraan antar sesama dalam hidup bermasyarakat. Bentuk kegiatan tersebut biasanya dilakukan oleh warga pondok pesantren atau madarsah apabila ada warga sekitar yang terkena musibah kematian, sebagian dari mereka ikut mengurus jenazah.

Bentuk pengorganisasian layanan khusus pondok pesantren di MAM NU Kota Blitar merupakan pembagian anggota terhadap bidang tugas masing-masing sehingga tujuan dari lembaga dapat tercapai. Pengorganisasian diawali dengan mengorganisir person untuk mengisi jabatan-jabatan yang ada. Anggota yang sudah ditetapkan dalam jabatannya akan dibagi ke masing-masing job description. Sruktur organisasi yang ada di Yayasan Lembaga Pendidikan Ma'arif Kota Blitar dimulai dari kedudukan tertinggi yaitu, PCNU Kab/Kota Blitar, BPPAB/LP Ma'arif NU, Direktur/ Pimpinan Ponpes, Wakil direktur, Pengasuh Asrama, Kepala Madin, Kepala Madrasah, Kepala Poskestren serta Kopontren. Hal ini sesuai dengan pernyataan yang dikemukakan oleh Hasibuan (dalam Sujarwo, 2012:33) yang dimaksud pengorganisasian adalah suatu proses menentukan, mengelompokkan dan pengaturan secara bersama dalam suatu kegiatan untuk mencapai tujuan, menentukan orang-orang yang akan melakukan aktivitas atau kegiatan, menyediakan alat yang diperlukan, menetapkan wewenang yang dapat didelegasikan kepada setiap individu yang akan melaksanakan aktivitas atau kegiatan.

Pelaksananaan layanan khusus pondok pesantren di MAM NU Kota Blitar berlangsung sesuai program yang telah direncanakan pada awal tahun pelajaran baru. Baik program kerja madrasah maupun asrama dapat dilaksanakan dengan baik. Jadwal yang diterapkan untuk santri baru pun dapat diikuti oleh mereka. Kegiatan pembelajaran pagi yang dimulai jam 07.00 sampai jam 12.00, pembelajaran sore jam 13.20 sampai jam 16.00, dan pembelajaran malam jam 18.30 sampai jam 20.00. pembelajaran pagi hari sudah dapat dikatakan tertib karena seluruh santri dapat mengikuti pembelajaran dengan baik dan tidak ada yang berkeliaran diluar kelas 
ketika jam pelajaran berlangsung. Kondisi ini sangat jauh berbeda dengan pelaksanaan pembelajaran pada malam hari. Karena pada pembelajaran malam hari masih ditemukan santri yang tidak ikut belajar dan mereka juga berkeliaran sehingga mengganggu santri lain yang sedang belajar. Para pendamping sudah berusaha menegur dan memperingatkan mereka agar mengikuti kelas. Namun, para santri masih saja ada yang mengindahkan teguran tersebut. Hal ini sesuai dengan pendapat Westra (dalam Rahardjo Adisasmita, 2011) pelaksanaan yaitu sebagai usaha-usaha yang dilakuakan untuk melaksanakan semua rencana dan kebijaksanaan yang telah dirumuskan dan ditetapkan dengan melengkapi segala kebutuhan alat-alat yang diperlukan, siapa yang akan melaksanakan, dimana tempat pelaksanaannya dan kapan waktu dimulainya. Selain kegiatan pembelajaran, kegiatan lain yang sudah dapat terlaksana dengan baik yaitu jadwal makan santri. Setiap hari santri mendapat makan 3 kali yaitu pagi, siang dan malam. Hal ini juga merupakan tugas dari seorang pendamping asrama yaitu menyediakan makan/ minum, mengemasi alat-alat dan sisa makanan, mencuci piring, sendok, gelas, menyimpan sisa makanan, serta mengantar makanan/minuman jatah penghuni yang sakit (Kusmintardjo, 1992:13-18).

Kegiatan pengawasan yang dilakukan di MAM NU Kota Blitar dilakukan dalam waktu 24 jam. Baik pengasuh maupun pendamping selalu mengawasi seluruh kegiatan para santri mulai dari bangun sampai tidur lagi. Sehingga para santri dapat dikendalikan dengan mudah. Pengawasan layanan khusus pondok pesantren di MAM NU Kota Blitar merupakan kegiatan evaluasi, menilai dan mengukur pelaksanaan, apakah telah sesuai dengan tujuan yang telah ditetapkan sebelumnya pada perencanaan. Pengawasan dilakukan oleh seluruh civitas akademik yayasan yang dilakukan satu bulan sekali. Pihak yang melakukan penilaian atau evaluasi secara langsung adalah pimpinan yayasan untuk keseluruhan. Sedangkan dalam lingkup madrasah dipimpin oleh kepala madrasah, lingkup pondok pesantren dipimpin oleh pengasuh, serta lingkup madin dipimpin oleh kepala madin. Pelaksanaan evaluasi dilaksanakan sesuai jadwal yang sudah ditentukan. Evaluasi terhadap program kerja disesuaikan dengan komponen-komponen yang dibutuhkan disetiap lembaga. Di MAM NU Kota Blitar, program yang dievaluasi bersifat menyeluruh sesuai dengan keadaan yang ada. Sehingga memudahkan warga madrasah dalam mengevaluasi, kegiatan apa yang sudah tercapai dan terlaksana dan kegiatan apa yang belum dapat dilaksanakan. Hal ini sesuai dengan pendapat Sujarwo (2012:62) fungsi evaluasi sebagai serangkaian kegiatan yang sistematis yang dilakukan dalam rangka untuk mengetahui apakah suatu kegiatan pendidikan telah berjalan sesuai dengan tujuan yang telah ditetapkan atau belum. Pelaksanaan proses evaluasi tidak hanya dilakukan sekali saja, tapi harus sering dilakukan (bertahap) sesuai lamanya kegiatan dilakukan. Evaluasi juga dilaksanakan secara kontinyu dan dilaksanakan bersama dengan melibatkan seluruh warga madrasah dan pondok pesantren.

\section{KESIMPULAN DAN SARAN}

\section{Kesimpulan}

Berdasarkan hasil penelitian dan pembahasan tersebut, dapat disimpulkan bahwa manajemen layanan khusus pondok pesantren di MAM NU Kota Blitar yaitu pertama perencanaan dilakukan pada awal tahun pelajaran baru. Kegiatan tersebut dilakukan dalam bentuk workshop yang diikuti oleh pimpinan yayasan, kepala madrasah, pengasuh asrama, kepala madin serta ustadz dan ustadzah. Selain itu, juga menyusun jadwal harian santri. Kedua, pengorganisasian dilakukan dengan menyusun struktur organisasi madrasah, yang meliputi Ketua yayasan, kepala madrasah, komite, pembina, kaur TU, waka, dan dewan ustadz dan ustadzah. Selain itu, juga terdapat job description masing-masing jabatan, yang sudah tertulis di Surat Keputusan. Ketiga, pelaksanaan terdiri dari implementasi program kerja yang telah direncanakan, baik program kerja pendidikan formal dan nonformal yang dilaksanakan secara beriringan. Kegiatan pendidikan formal yaitu pembelajaran pagi hingga siang hari, sedangkan non formal dilaksanakan pada malam hari. Implementasi jadwal harian santri yang sudah disusun pada awal tahun pelajaran baru. Sistem pendistribusian makan untuk para santri serta jadwal pengambilannya. Keempat, pengawasan lebih mengarah pada kegiatan evaluasi programprogram yang dilakukan oleh seluruh ustadz dan ustadzah yang dipimpin langsung oleh pimpinan 
yayasan. Waktu pelaksanaan rapat evaluasi madrasah dilakukan satu bulan sekali, madin satu minggu sekali dan ponpes satu minggu sekali. Komponen-komponen yang dievaluasi meliputi ketertiban dan kedisiplinan mulai santri bangun tidur sampai santri tidur kembali, dan ketercapaian program pendidikan.

\section{Saran}

Berdasarkan kesimpulan tersebut, maka peneliti memberikan saran terhadap beberapa pihak, yaitu pertama Kepala MAM NU Kota Blitar, sebaiknya juga turut serta dalam mengelola Ponpes sehingga dapat mengetahui kekurangan yang dimiliki di ponpes. Kedua, Kepala Madrasah Diniyah MAM NU Kota Blitar, sebaiknya semua kelas madin dilaksanakan di ruang kelas dan tidak diasrama. Karena, jika terdapat santri yang tidak mengaji tidak akan mengganggu pandangan atau konsentrasi santri yang sedang madin. Ketiga, Pengasuh Asrama MAM NU Kota Blitar, memperbarui kembali tata tertib yang ada di asrama dan sanksi-sanksi dipertegas agar para santri jera. Keempat, Pendamping Asrama MAM NU Kota Blitar, lebih meningkatkan kedisiplinan untuk santri yang tidak mengikuti kegiatan madin dan memberikan sanksi yang tegas supaya santri yang lain tidak mengikuti. Kelima, Peneliti lain diharapkan dapat melanjutkan penelitian sejenis pada berbagai aspek lain, dan penelitian ini dapat dijadikan sebagai bahan rujukan tanpa melupakan nilai keaslian dalam penelitian di bidang manajemen layanan khusus pondok pesantren.

\section{DAFTAR RUJUKAN}

Adisasmita, R. 2011. Pengelolaan pendapatan dan Anggaran Daerah. Yogyakarta: Graha Ilmu.

Aryawiga. 2012. Manajemen Layanan Khusus Sekolah. (Online), (http://aryawiga.wordpress. com/2012/02/17/manajemen-layanan-khusussekolah/), diakses pada 2 April 2015.

Kusmintardjo. 1992. Pengelolaan Layanan Khusus di Sekolah (Jilid II). Malang: IKIP Malang.

Moleong, L. 2005. Metodologi Penelitian Kualitatif: Edisi Revisi.Bandung: PT Remaja Rosdakarya.

Triwiyanto. T. 2015. Pelaksanaan Monitoring, Evaluasi, dan Pelaporan Untuk Penilaian Kinerja Manajerial Kepala Sekolah. Cakrawala Pendidikan. XXXIV (1): 67-77.
Ulfatin, N. 2013. Metodologi Penelitian Kualitatif di Bidang Pendidikan: Teori dan Aplikasinya. Malang: Banyumedia.

Wiyono, B.B. 2007. Metodologi Penelitian: Pendekatan Kualitatif, Kuantitatif, dan Action Research (Burhanuddin, Ed). Malang: Fakultas Ilmu Pendidikan Universitas Negeri Malang. 